Desirée Pangerc

\title{
Forced and Illegal Migrations from the Western Balkans to Europe: An Applied Anthropology of Security Approach
}

Globalization, migrations and security issues are strictly connected $^{1}$ : but, if we can consider globalization and migration as "total social facts" - as we say in anthropology ${ }^{2}$ because every element or representation of the economical, social, political, cultural and religious aspects are involved in this human experience, we have to underline also the "dark side" of this duo. Especially from the 90s thenceforth, we have been observing a continuous increase of two criminal phenomena linked to forced and illegal migrations: smuggling of migrants and human trafficking.

The first one is defined as the facilitation, transportation, attempted transportation or illegal entry of a person or persons across an international border, in violation of one or more countries laws, either clandestinely or through deception, such as the use of fraudulent documents ${ }^{3}$. The second one is defined

${ }^{1}$ D.M. Goldstein, Towards a critical anthropology of security, "Current Anthropology" 2010, vol. 51, no. 4, pp. 487-517.

${ }^{2}$ S. Palidda, Introduzione, [in:] A. Sayad, La doppia assenza. Dalle illusioni dell'emigrato alle sofferenze dell'immigrato, Milano 2002, p. IX.

${ }^{3}$ Fact Sheet: Distinctions Between Human Smuggling and Human Trafficking, U.S. Department of State, January 1, 2006, http://www.state. gov/m/ds/hstcenter/90434.htm. 
as follows by Article 3, paragraph (a) of the Protocol to Prevent, Suppress and Punish Trafficking in Persons: The recruitment, transportation, transfer, harbouring or receipt of persons, by means of the threat or use of force or other forms of coercion, of abduction, of fraud, of deception, of the abuse of power or of a position of vulnerability or of the giving or receiving of payments or benefits to achieve the consent of a person having control over another person, for the purpose of exploitation. Exploitation shall include, at a minimum, the exploitation of the prostitution of others or other forms of sexual exploitation, forced labour or services, slavery or practices similar to slavery, servitude or the removal of organs... The consent of a victim of trafficking in persons to the intended exploitation set forth [above] shall be irrelevant where any of the means set forth [above] have been used ${ }^{4}$.

These two kind of exploitation of human beings became a priority in the International Community agenda: the 2013 statistics say about 20.9 million of victims trafficked worldwide, an underground industry of 32 billion dollars per year. The United Nations Office on Drugs and Crime (UNODC) report Trafficking in persons to Europe for sexual exploitation shows that this is one of the most lucrative illicit businesses in Europe, where criminal organizations are making around 2.5 billion dollars per year, especially through sexual exploitation and forced labour ${ }^{5}$.

And - only in the European Union - up to 70,000 additional victims are exploited every year. Half of them come

${ }^{4}$ Protocol to Prevent, Suppress and Punish Trafficking in Persons, especially Women and Children, supplementing the United Nations Convention Against Transnational Organized Crime, UNODC, 2000, http://www.uncjin.org/Documents/Conventions/dcatoc/final_documents_2/convention_\%20traff_eng.pdf.

${ }^{5}$ Trafficking in persons to Europe for sexual exploitation, UNODC, 2010, http://www.unodc.org/documents/human-trafficking/UNVTF_fs_HT_EN.pdf. 
Forced and Illegal Migrations from the Western Balkans... 183

from the Balkans (32\% more or less) and the former Soviet Union (19\%), with $13 \%$ originating in South America, $7 \%$ in Central Europe, 5\% in Africa and 3\% in East Asia.

As to the statistics regarding the smuggling of migrants, they estimate an annual income of 20 billion dollars for the criminal groups, but the number of smuggled people differs in each report. We can just take for granted that the percentage of smuggled migrants is much higher than that one of trafficked victims.

In fact, the characteristics of the two criminal phenomena (as organized - and in large part transnational) result in a high dark number and make trafficking [and smuggling] hard to identify, to control and to prevent $[\text { them }]^{6}$ : for several reasons, the crime is not readily reported to the police and the victims are extremely reluctant to cooperate with the judicial operators, so we can only rely on the data given by the border police or the non-governmental organizations (NGOs) which operate in the assistance of the victims ${ }^{7}$.

\section{The "Italian Model" and its Success}

At the beginning of my research, I was trained by a great Italian Anti-mafia Prosecutor, Nicola Maria Pace, who

${ }^{6}$ K. Aromaa, Trafficking in Human Beings: Uniform Definitions for Better Measuring and for Effective Counter-Measures, [in:] Measuring Human Trafficking. Complexities and Pitfalls, [eds.] E.U. Savona, S. Stefanizzi, New York 2007, p. 20.

${ }^{7}$ For more, see: D. Pangerc, Il traffico degli invisibili. Migrazioni illegali lungo le rotte balcaniche, Roma 2012; eadem, Illegal Migrations Along the Balkan Routes, "Journal of Social Sciences" 2012, vol.: Special Issue on Balkans, Süleyman Demirel University. Faculty of Arts and Sciences, pp. 139-147, http://sablon.sdu.edu.tr/dergi/sosbilder/dosyalar/27/OS_12.pdf. 
explained me the "Italian model" and its application to combat these two social scourges. This successful model is characterized by four aspect:

1. the differentiation of every flux of immigrants from the others. The differentiation on ethnical bases showed that every criminal group works in a different way, from the recruitment of the victims to the modalities through which they segregate them, once enslaved ${ }^{9}$;

2. the analysis of criminal organizations in their transnational dimension, comparing their structure to the one of transnational holdings. As Jean Ziegler demonstrates in his research ${ }^{10}$, the new mafias are characterized by:

a. a financial and economical capitalistic structure whose parameters are the maximization of the profit, a vertical control and the productivity;

b. a military hierarchy, which means that every criminal organization has its roots in the extreme violence, is the subject to capital accumulation, territorial domination and the conquest of the markets; there is a command-obedience relationship, obtained through an authoritarian method;

c. an ethnical structure ${ }^{11}$ or the form of a "coalition", that is a temporary alliance to reach a specific goal/some specific goals ${ }^{12}$.

${ }^{8}$ F. Spiezia, F. Frezza, N.M. Pace, Il traffico e lo sfruttamento di esseri umani. Primo commento alla legge di modifica alla normativa in materia di immigrazione ed asilo, Milano 2002.

${ }^{9}$ Ibidem.

${ }^{10}$ J. Ziegler, I signori del crimine, Milano 2000 (original work published in 1998 in France: Les seigneurs du crime. Les nouvelles mafias contre la démocratie).

${ }^{11}$ Ibidem.

${ }^{12} \mathrm{~J}$. Boissevain, Friends of Friends. Networks, Manipulators and Coalitions, New York 1974, p. 171. 
Forced and Illegal Migrations from the Western Balkans... 185

These three characteristics exclude one another in everyday life, but by interconnecting them, the criminal organization obtains the maximum level of effectiveness.

3. to diversify the general phenomenon called "trafficking in human beings" in sub-phenomena:

a. trafficking in women and minors for sexual exploitation;

b. trafficking in men, women and minors for labor exploitation;

c. the issue regarding the so-called argati" ${ }^{13}$ or minors "in leasing";

d. human organs trade;

e. illegal adoptions;

f. forced marriage;

g. money laundering, obviously connected to the previous illicit activities.

This model was used in several police operations, assuring their success: the most famous is Operazione Oriente 1. This operation conducted to the dismantling of

${ }^{13}$ Argat or "slave" is a Roma term used in opposition to gazda, which means "owner". This phenomenon refers to the buying and selling of childres, common issue among some Roma communities but also in the rural Albania. In fact, in some parts of Albania, every aspect of life is still disciplined by the Kanun, a code of 1,262 articles which regulate all aspects of the mountainous life: economic organization of the household, hospitality, brotherhood, clan, boundaries, work, marriage, land, and so on. In Book Three "Marriage", Chapter Six "The Family", article XXXIII, paragraph 59, we can read: The father has the right: a) over the life and sustenance of his sons; b) to beat, bind, imprison, or even to kill his son and daughter without being liable before the law, which considers this to be the same as suicide [...]; c) to place his son in paid service as many times as he likes [...]; d) over the earnings of his son, whatever these may be; e) to sell and to buy, to give and to take, Kanuni i Lekë Dukagjinit = The Code of Lekë Dukagjini, transl. by L. Fox, New York 1989, p. 44. 
a transnational criminal network committed to human trafficking and smuggling of migrants, whose leader was a boss of the Chinese mafia, Xu Bailing. The main cell, formed by Bailing and two Croatian mafiosi, was controlling a criminal activity which yielded an amount of 130 billion Italian lire (99 million dollars) per year and which illegally introduced 5,000 migrants from the Far East to Italy in just over 9 months.

According to the Prosecutor, some of these migrants were considered "special loads", because they were destined to the organ trade, with the possible killing of the smuggled persons. Moreover, some scabrous details emerged from the wiretappings, for instance the physical violence used by the slave drivers on the victims, like brawls or other form of tortures, in order to facilitate further payments for the transit of the human merchandise.

In the so-called "bull's game", two migrants were obliged to headbutt each other, while the slave drivers of the different sorting centres recorded their painful screams in order to send the tapes to the families or friends of the victims in the country of origin. The criminal network also decided to sell the migrants to another criminal group or not and, if this happened, the new slave drivers demanded further money for the transit of the victims ${ }^{14}$.

After Oriente 1, a lot of counter-trafficking operations used the same model with success: this is why the Italian model was exported abroad, especially in the Balkans, through various meetings of the Ministries of the Interiors and the other actors of the judicial cooperation.

${ }^{14}$ D. Pangerc, Il traffico degli invisibili... 
Forced and Illegal Migrations from the Western Balkans... 187

\section{The Importance of International Police Cooperation}

Recent changes in the perception and understanding of security have made effective border security systems as well as comprehensive international police cooperation increasingly important. In many cases, improving a country's frontier controls necessitates extensive legal, organizational and structural changes.

International police cooperation requires international agreements, on the one hand, and a national implementation administrative framework, on the other hand, in order to apply these agreements properly. As an example, I would like to describe the structure of the Police Cooperation Convention for Southeast Europe, with its headquarter based in Ljubljana (Slovenia) and I will give some information I gathered when I visited it in January 2013.

On 5 May 2006 in Vienna, during the Austrian presidency of the European Union, the Ministers of Interior from Albania, Bosnia and Herzegovina (BiH), Macedonia, Moldova, Montenegro, Romania and Serbia, signed the Police Cooperation Convention for Southeast Europe (PCC-SEE). After ratification by all seven signatory states, the Convention entered into force on 10 October 2007. In addition, Bulgaria acceded to the Convention on 25 September 2008, Austria - on 24 May 2011, Hungary - on 6 July 2012 and Slovenia - on 14 December 2012.

Its Secretariat is hosted by Democratic Control on Armed Forces (DCAF) ${ }^{15}$ Ljubljana. The Secretariat became operational on 1 September 2008. The work of the Secretariat is executed by DCAF Ljubljana staff and secondees from Donor Countries and Contracting Parties.

${ }^{15}$ An international foundation located in Geneva with permanent offices in other countries, for more, see: http://www.dcaf.ch. 
PCC-SEE, under the political guidance of the Committee of Ministers and the supervision of the Expert Working Group, the Secretariat is mandated with the following main goals: to execute the tasks specified by the Committee of Ministers and the Expert Working Group; to coordinate and catalogue all Convention related activities; to promote the exchange of the most succesful practices among the Contracting Parties; to organize the meetings of the Committee of Ministers and the Expert Working Group; to be the contact point for the Contracting Parties and the international partners; to give assistance for the implementation of the Convention; to create a list of experts for every field relevant to the PCC-SEE activities; to report on its functions and activities under the Convention directly to the Committee of Ministers at ministerial meetings, or indirectly through the Expert Working Group; finally, to keep the partners and the public informed about its developments.

The main activities for the full implementation of the Convention are based on three pillars: the decision-making process, the implementation programme and the operational cooperation. As to the first pillar, article 33 of the Convention states that the Committee of Ministers decides unanimously on the implementation, interpretation and application of the Convention. The decision making process of the Committee is modeled on the practice of the European Union in order to be more effective and transparent. One of the bodies involved in the decision making process is the Expert Working Group, whose role is to monitor the application and the implementation of the Convention and to make recommandations to the Committee of Ministers.

As to the implementation programme pillar, with the support of international partners, Contracting parties are 
Forced and Illegal Migrations from the Western Balkans... 189

preparing the establishment of operational capabilities for full implementation of the Convention.

As to the operational cooperation pillar, the Convention itself provides a toolbox for operational cooperation, which should start almost immediately.

The activities carried on are several: joint threat analysis, liaison officers, hot pursuit, witness protection, cross-border surveillance, controlled delivery, undercover investigations to investigate crimes and to prevent criminal offences, transmission and comparison of DNA profiles and other identification material, technical measures for facilitating transborder cooperation, border search operations, mixed analysis working groups, joint investigation teams, mixed patrols along the state border and cooperation in common centres ${ }^{16}$.

I analyzed the PCC-SEE Cooperation because it is one of the coordination and operative organisms I am familiar with better and because it is an initiative implemented mainly by the Western Balkans, but there are also others we shoud mention, for instance Eurojust, whose mission is to support, stimulate and strengthen coordination and cooperation between national investigating and prosecuting authorities in relation to serious crime affecting two or more European Union Member States ${ }^{17}$.

The main problems, these coordination structures are forced, is to the lack of fundings to implement all the activities and to find a long-term strategy focused on the vocational training of the border police, in order to eradicate the problems of the corruption or, even worse, the connivance between the police officers and the criminal groups.

${ }^{16}$ Information retrieved from http://www.pccseesecretariat.si.

${ }^{17}$ http://eurojust.europa.eu/Pages/home.aspx. 


\section{Researching on the Field}

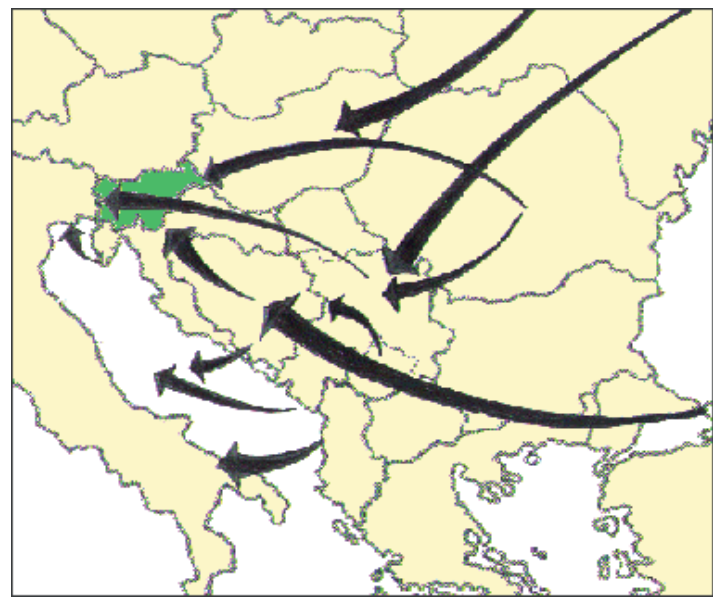

Figure 1. Illegal migrations fluxes through the Balkans Source: http://www.pccseesecretariat.si

As we can see in the figure above, the Western Balkans are a very complex net in which immigrants' fluxes can be channeled by the criminal groups involved in smuggling and human trafficking. All this area is a hub from routes which starts from Afghanistan, Iran, Turkey and now, after the recent political events, from North Africa.

In 2006, I decided to follow one of these routes from a country of arrival, Italy, through some countries of transit, such as Slovenia and Croatia, and then to stop in Bosnia and Herzegovina. I was doing my fieldwork there between 2008 and 2010 and the reason of my choice was the peculiar situation - regarding especially human trafficking - I discovered after some months spent on the field ${ }^{18}$.

${ }^{18}$ D. Pangerc, Il traffico degli invisibili... 
Forced and Illegal Migrations from the Western Balkans... 191

I arrived in Bosnia and Herzegovina in the middle of September 2008. There, I officially started to work as a Programme Officer for the Local Technical Unit of the Italian Embassy in Sarajevo. My work consisted in evaluating and monitoring all the Italian cooperation initiative in the country, especially those concerning the justice system and the protection of the vulnerable social groups.

Bosnia and Herzegovina is what David Thuerer defines a "failed State"19: a State in which state institutions collapsed - especially the police and the judiciary system, the organs devoted to the activities of control and monitoring. The result is a paralysis of governance, a breakdown of law and order, and general social chaos; on the other hand, there is an expansion of illicit markets and trades, for instance human trafficking.

I said before that I considered myself as a perfectly prepared researcher because I studied the historical background of the country, the socio-political situation ${ }^{20}$ and the approach to the victims of human trafficking. When I met one of the most experts in human trafficking, operating there for one Cooperation Agency, he quickly stopped my introduction, in order to reply: But there is no human trafficking here in BiH. Have you read the Trafficking in Persons report?21 Bosnia and

${ }^{19}$ For more, see: D. Thuerer, The 'failed state' and international law, "International Review of the Red Cross" 1999, no. 836, pp. 731-761. Some scholars could argue that the Western Balkans cannot be defined "failed States" but only "weak States", according to the Failed States Index 2008 or the following ones. I continue to be very cautious with indexes and statistics, because I experienced on the field what I write and I prefer qualitative analysis rather than contrasting data.

${ }^{20}$ Balkans: Foreign Affairs, Politics and Socio-Cultures, eds. C. Yenigün, F. Gjana, Tirana 2011.

${ }^{21}$ The Trafficking in Persons (TIP) Report is the U.S. Government's principal diplomatic tool to engage foreign governments on human 
Herzegovina was promoted, the country is in the II Tier, its government made great efforts in fighting against human trafficking and was successful.

In fact, in the past $\mathrm{BiH}$ has generally assessed as a country of transit and destination for victims - especially women from Eastern Europe. With a lot of operative measures to control the borders and with the key-role performed by the International Police Task Force till 2003, the procedures to smuggle the victims in and out of the borders were too risky for the criminal organizations, so the external trafficking came to an end ${ }^{22}$. Statistics showed that. But Benjamin Disraeli's words give us a help: There are three kinds of lies: the big lies, the small lies... and the statistics. Obviously I agree with him, because Bosnia and Herzegovina is still a country where this human right violation is still present.

When I met the assistant of the State Coordinator for Counter-Trafficking in $\mathrm{BiH}$, she told me: You ask me how organized crime operates here, but I have to tell you that only two local mafiosi trafficked in human beings, Milaković - who operated in Prijedor - in the past and now Kučević who operated in Tuzla - Kučević was convicted in 2009, while I was in Sarajevo. But the local newspapers continuously reported

trafficking. It is also the world's most comprehensive resource of governmental anti-human trafficking efforts and reflects the U.S. Government's commitment to global leadership on this key human rights and law enforcement issue. It represents an updated, global look at the nature and scope of trafficking in persons and the broad range of government actions to confront and eliminate it, Trafficking in Persons Report, U.S. Department of State, http:// www.state.gov/j/tip/rls/tiprpt/2013/.

${ }^{22}$ Report on the situation of trafficking in human beings and illegal immigration in Bosnia and Herzegovina and Report on the implementation of the Action Plan for combating trafficking in human beings and illegal immigration in Bosnia and Herzegovina, Organization for Security and Co-operation in Europe, 2007. 
cases of trafficked people, not trafficked by criminal groups but by common people, NGOs continued to ask the Donors Community for money to finance shelters, rehabilitation activities and so on. And she explained me: You are asking about mafia. The problem here is that common people started to traffic women and minors. You cannot believe it, but last week we discovered three women enslaved by a mother and her son in a village not far from here ${ }^{23}$.

The Italian model I had in my mind was not useful to continue my researches: I had to change my methodology and to start thinking about crime perception ${ }^{24}$. First of all, I was on the field in order to put in practice the active participant observation, theorized by Bronislaw Malinowski, by collecting facts and not data; to adopt a mimetic approach, useful to create my social network and to analyze the others; to use an actor-oriented approach, by dividing the network of my gate-keepers into three levels; an informal one, formed by people; an operative one, i.e. experts from the European Union Force (EUFOR) and the European Union Police Mission (EUPM), local police, social operators from NGOs; finally, an institutional one.

What I found through this method was that the country had been increasingly starting to face a new form of human trafficking, whereby Bosnian women and minors - minors especially from the Roma communities - were being recruited and exploited within its borders. This internal trafficking is harder as we can only find out about by special intelligence and surprise raids, both requiring a lot of resources and impossible to keep up as a standard approach, an investigator noted ${ }^{25}$.

\footnotetext{
${ }^{23}$ D. Pangerc, Il traffico degli invisibili..., p. 169.

${ }^{24}$ A. Bauer, Dernières nouvelles du crime, Paris 2013.

${ }^{25}$ K. Aromaa, op. cit., p. 18.
} 
As to the statistics - mostly provided by NGOs which are on the field, the number of identified victims of trafficking in human beings for the purpose of sexual exploitation stagnated since 2003. However, in 2007, although the number of identified victims of trafficking in human beings for the purpose of sexual exploitation was the lowest since this phenomenon has been monitored systematically, the number of citizens of Bosnia and Herzegovina who had been identified as victims of trafficking in human beings for the purpose of sexual exploitation within its borders, for the first time exceeded the number of identified foreign victims of trafficking in human beings. The $44 \%$ of the total identified victims were minors, all from $\mathrm{BiH}^{26}$ : the number of children working on the streets was constantly rising, due to the lack of efficient mechanism of protection by relevant institutions, particularly among minority groups, such as Roma as I said before.

Another big problem was the involvement of common people in this trade: human trafficking was no more considered a crime sensu stricto, but "just a business" for normal people. Big criminal groups decided to choose other illicit trades, such as arms and drugs, easier to manage. The traffic changed its operational context: single criminals or common people created an internal market, in order not to cross anymore borders the country, with the high possibility to be arrested. Consequently, this explains why the victims were recruited among Bosnian girls and minors and not from the other countries any more. Moreover, this underlines once more the scarce

${ }^{26}$ Trafficking in Human Beings and Responses of the Domestic Criminal Justice System. A Critical Review of Law and Emerging Practice in Bosnia and Herzegovina in Light of Core International Standards, Organization for Security and Co-operation in Europe. Mission to Bosnia and Herzegovina, Sarajevo 2009, http://www.oscebih.org/documents/osce_bih_doc_2009070710460618eng.pdf. 
involvement of the civil society and the lack of information regarding what local Institutions $\mathrm{do}^{27}$ : this situation is quite common in all the Western Balkans.

Anyway, according to the TIP 2008, the great efforts made by the Bosnian government to combat the phenomenon through a normative framework, the creation of a State Office dedicated to the issue, the organization of a coalition of 5 NGOs to assist the victims and the significant reduction of the number of people trying to pass the border illegally, proved that $\mathrm{BiH}$ was a virtuous country: the dyscrasia between rules/statistics and reality is evident. And it was more evident during my second short mission in BiH in July 2012: after the results of the TIP Report, the International Community decided that there was no need to fund the initiatives to combat human trafficking: so the State Coordinator became a role without importance and the NGOs coalition was broken. Only one of them is still trying to provide assistance to the victims and to protect them in the shelters.

On August 2013, I did a short fieldwork in the Republic of Macedonia/FYROM: according to the TIP Report 2013, the country was placed in Tier 1, i.e. the level in which we find the countries which fully complies with the minimum standards required for the elimination of trafficking. But, in the same report, we can read that Macedonia is a source, transit, and destination country for men, women, and children subjected to sex trafficking and forced labor. Macedonian women and girls are subjected to sex trafficking and forced labor within the country in bars, nightclubs, and in begging on the street. Children, primarily ethnic Roma, are forced to beg by their families. The age of identified victims is increasingly younger and more victims originate from neighboring countries.

${ }^{27}$ Report on the situation of trafficking in human... 
Foreign victims in Macedonia originate from Albania, Bulgaria, Serbia, Bosnia, Ukraine, and Kosovo. Macedonian citizens are subjected to trafficking in Greece, Belgium, and other countries in Europe. According to the police, the cities of Tetovo and Kumanovo are the main centres or hubs of this illicit trade.

\section{Conclusions}

As I said previously, the common perception in $\mathrm{BiH}$ but also in the most of the states of the Western Balkans is that human trafficking is just a business (mainly for the traffickers but also for the trafficked because of their extreme poverty) and not a crime against humanity. So the challenge is to change this wrong perception and to work on raising awareness among civil society. Moreover, it is very important to stop this human rights violation to focus on the victim status, that is criminal justice intervention must ensure victim protection and assistance: this because victims are fundamental as witnesses during the trials.

As Jo Goodey says ${ }^{28}$, the treatment of trafficked women as victims of crime and their treatment as criminal justice informants are different between European Union Member States and not European Union Member States and this is a very big problem. It is very hard to identify a victim who does not co-operate or, as often happens, denies his/her status, does not accept our view of him/her as a potential or real victim [...]. It is also clear that if the victim role is not beneficial

${ }^{28}$ J. Goodey, Sex trafficking in women from Central and East European countries: promoting a 'victim-centred' and 'woman-centred' approach to criminal justice intervention, "Feminist Review" 2004, no. 76, pp. 26-45. 
to the presumed victim, he/she will have no reason to come to $u s^{29}$. The weak legal status of the victims in the legislations of most nation states contributes to their reluctance to report the crimes and to co-operate with authorities during the investigation and court proceedings $\mathrm{s}^{30}$.

So, by working on crime perception and through an anthropological perspective, my suggestions are:

1. the International Community and the local government must continue work on raising awareness among civil society and on prevention campaigns;

2. an adequate vocational training of the local police and social operators is also required in order to ensure the success of the operations and, after, the collaboration of the victims (this vocational training should be carried on by high specialized expert with a cross-cutting approach);

3. a more structured coordination between institutional, judicial and social actors allow to cut expenses for small projects and to channel resources for an effective long-term strategy in counter-trafficking ${ }^{31}$.

So, anthropology of security and action anthropology can offer a great contribution in fully understanding the holistic dimension of illegal and forced migrations, also by playing a pivotal role in the prevention phase in the country of origin and not only in the emergency one in the countries of destination.

Anthropology of security provides the theoretical framework regarding the relationships between security discourse

${ }^{29}$ K. Aromaa, op. cit., p. 19.

${ }^{30}$ Ibidem, p. 20.

${ }^{31}$ See: D. Pangerc, Anthropological Methods in Counter-Trafficking Activities: Analysis of Criminal Networks and Victim-Oriented Approach, [in:] Anthropology and Security Studies, [eds.] F. Anton Hurtado, G. Ercolani, Murcia 2013. 
and practice, human and civil rights, and the entailments of neoliberalism by offering a perspective on these issues that is at once ethnographically sensitive and attuned to contemporary global interconnections ${ }^{32}$, while action anthropology, being a scholarly enterprise based in field research, data collection, and theory building, during which the anthropologist is also committed to assisting local communities in achieving their goals and meeting specific felt needs, [...] contributes to the community while learning from their experiences [...] and discovers local concerns in the course of ethnographic work and engages local resources in addressing them ${ }^{33}$.

\section{References}

Aromaa K., Trafficking in Human Beings: Uniform Definitions for Better Measuring and for Effective Counter-Measures, [in:] Measuring $\mathrm{Hu}$ man Trafficking. Complexities and Pitfalls, [eds.] E.U. Savona, S. Stefanizzi, New York 2007

Balkans: Foreign Affairs, Politics and Socio-Cultures, eds. C. Yenigün, F. Gjana, Tirana 2011

Bauer A., Dernières nouvelles du crime, Paris 2013

Boissevain J., Friends of Friends. Networks, Manipulators and Coalitions, New York 1974

Buzan B., Hansen L., The Evolution of International Security Studies, Cambridge 2009

Encyclopedia of Anthropology, ed. J. Birx, vol. I, London 2006

Esman M.J., Diasporas in the Contemporary World, Cambridge 2009

Fact Sheet: Distinctions Between Human Smuggling and Human Trafficking, U.S. Department of State, January 1, 2006, http://www.state.gov$/ \mathrm{m} / \mathrm{ds} / \mathrm{hstcenter} / 90434 . \mathrm{htm}$

Goldstein D.M., Outlawed. Between security and rights in a Bolivian city, Durham 2012

${ }^{32}$ D.M. Goldstein, op. cit., p. 487.

${ }^{33}$ Encyclopedia of Anthropology, ed. J. Birx, vol. I, London 2006, p. 56. 
Forced and Illegal Migrations from the Western Balkans... 199

Goldstein D.M., Towards a critical anthropology of security, "Current Anthropology" 2010, vol. 51, no. 4

Goodey J., Sex trafficking in women from Central and East European countries: promoting a 'victim-centred' and 'woman-centred' approach to criminal justice intervention, "Feminist Review" 2004, no. 76

Kanuni i Lekë Dukagjinit = The Code of Lekë Dukagjini, transl. by L. Fox, New York 1989

Palidda S., Introduzione, [in:] Sayad A., La doppia assenza. Dalle illusioni dell'emigrato alle sofferenze dell'immigrato, Milano 2002

Pangerc D., Anthropological Methods in Counter-Trafficking Activities: Analysis of Criminal Networks and Victim-Oriented Approach, [in:] Anthropology and Security Studies, [eds.] F. Anton Hurtado, G. Ercolani, Murcia 2013

Pangerc D., Il traffico degli invisibili. Migrazioni illegali lungo le rotte balcaniche, Roma 2012

Pangerc D., Illegal Migrations Along the Balkan Routes, "Journal of Social Sciences" 2012, vol.: Special Issue on Balkans, Süleyman Demirel University. Faculty of Arts and Sciences, http://sablon.sdu.edu.tr/dergi/ sosbilder/dosyalar/27/OS_12.pdf

Pangerc D., Processi migratori e traffico di esseri umani - Verso una differenziazione operativa del concetto, "Dedalus" [Milano] 2008, no. 5

Pangerc D., Trafficati. Esperienze di viaggio, "DADA. Rivista di Antropologia post-globale" 2011, Numero speciale 1: Antropologia del viaggio, http://www.dadarivista.com

Protocol to Prevent, Suppress and Punish Trafficking in Persons, especially Women and Children, supplementing the United Nations Convention Against Transnational Organized Crime, UNODC, 2000, http://www. uncjin.org/Documents/Conventions/dcatoc/final_documents_2/convention_\%20traff_eng.pdf

Report on the situation of trafficking in human beings and illegal immigration in Bosnia and Herzegovina and Report on the implementation of the Action Plan for combating trafficking in human beings and illegal immigration in Bosnia and Herzegovina, Organization for Security and Co-operation in Europe, 2007

Spiezia F., Frezza F., Pace N.M., Il traffico e lo sfruttamento di esseri umani. Primo commento alla legge di modifica alla normativa in materia di immigrazione ed asilo, Milano 2002 
The Globalization of Crime. A Transnational Organized Crime Threat Assessment, UNODC, 2010, http://www.unodc.org/documents/data-andanalysis/tocta/TOCTA_Report_2010_low_res.pdf

Thuerer D., The 'failed state' and international law, "International Review of the Red Cross" 1999, no. 836

Trafficking in Human Beings and Responses of the Domestic Criminal Justice System. A Critical Review of Law and Emerging Practice in Bosnia and Herzegovina in Light of Core International Standards, Organization for Security and Co-operation in Europe. Mission to Bosnia and Herzegovina, Sarajevo 2009, http://www.oscebih.org/documents/osce_ bih_doc_2009070710460618eng.pdf

Trafficking in humans: social, cultural and political dimensions, ed. by S. Cameron and E. Newman, New York 2008

Trafficking in Persons Report, U.S. Department of State, http://www.state. gov/j/tip/rls/tiprpt/2013/

Trafficking in persons to Europe for sexual exploitation, UNODC, 2010, http://www.unodc.org/documents/human-trafficking/ UNVTF_fs_HT_EN.pdf

Ziegler J., I signori del crimine, Milano 2000 